\title{
Essential oils in the diet of young bulls: Effect on animal performance, digestibility, temperament, feeding behaviour and carcass characteristics
}

\author{
Mariana G. Ornaghi ${ }^{\mathrm{a}, *}$, Rodrigo A.C. Passetti ${ }^{\mathrm{a}}$, Juliana A. Torrecilhas ${ }^{\mathrm{a}}$, \\ Camila Mottin $^{\mathrm{a}}$, Ana Carolina P. Vital ${ }^{\mathrm{b}}$, Ana Guerrero ${ }^{\mathrm{c}}$, Carlos Sañudo ${ }^{\mathrm{c}}$, \\ Maria del Mar Campo ${ }^{\mathrm{c}}$, Ivanor N. Prado ${ }^{\mathrm{a}}$ \\ a Department of Animal Science, Universidade Estadual de Maringá, Av. Colombo, 5790, 87020-900, Maringá, Paraná, Brazil \\ b Food Science Post-Graduate Program, Universidade Estadual de Maringá, Av. Colombo, 5790, 87020-900, Maringá, Paraná, Brazil \\ c Departmentof Animal Production and Food Science, Instituto Agroalimentario de Aragón-IA2 (Universidad de Zaragoza-CITA), Miguel Servet 177, \\ 50013 Zaragoza, Spain
}

\section{A R T I C L E I N F O}

\section{Keywords:}

Cinnamaldehyde

Cinnamon

Clove

Eugenol

Feedlot

\begin{abstract}
A B S T R A C T
With the increase of public concern over the routine use of antibiotics in livestock, the addition of plant extracts and essential oils (EOs) became a natural alternative in the diets since it might have similar antimicrobial properties as the ionophores. This study was conducted to evaluate the animal performance, temperament, feeding behaviour and carcass characteristics of 40 young crossbred bulls ( $1 / 2$ Brown Swiss $-1 / 2$ Nellore) at $10 \pm 2.2$ months of age with an average body weight of $219 \pm 11.7 \mathrm{~kg}$ without (control) the addition or with different levels ( 3.5 or $7.0 \mathrm{~g} /$ day per animal) of clove or cinnamon EOs in the diet. The finishing period in the feedlot was 187 days. Animal performance was higher $(P<0.05)$ in the group with EOs (both levels) than in the control group diet and increased linearly when EOs was added $(P \leq 0.05)$. The feed intake of dry matter and other nutrients was higher and increase linearly $(P<0.05)$ in young bulls fed with EOs independently of the type or dosage level. Feed efficiency and the digestibility in vitro were unaffected by dietary treatment $(P>0.05)$. The addition of clove or cinnamon EOs did not alter $(P>0.05)$ temperament or feeding behaviour. The cold carcass weight was higher $(P<0.05)$ in bulls from the EOs groups than in the control group. However, the carcass weight was similar $(P>0.05)$ between young bulls with EOs received clove or cinnamon in the diet. The muscle, fat and bone percentages and fat thickness, marbling, Longissimus muscle area and $\mathrm{pH}$ did not differ $(P>0.05)$ among diets. The results indicate that the EOs improved the animal performance of young bulls finished in high-concentrate diets did not alter carcass characteristics, temperament or feeding behaviour.
\end{abstract}

\section{Introduction}

Antibiotics are commonly used in the diets of animals in some countries to prevent diseases and metabolic disorders and to

\footnotetext{
Abbreviations: EOs, essential oils; BW, body weight; FBW, final body weight; OM, organic matter; DM, dry matter; DMI, dry matter intake; NDF, neutral detergent fiber; ADF, acid detergent fiber; CP, crude protein; DMD, digestibility of the dry matter; CCD, cold carcass dressing; CCW, cold carcass weight; LM, Longissimus muscle; GLM, general linear model; ADG, average daily gain; ORAC, Oxygen Radical Absorbance Capacity; SEM, standard error mean; ANOVA, analysis of variance

* Corresponding author.

E-mail address: marianaornaghi@hotmail.com (M.G. Ornaghi).
} 
improve feed efficiency. These additives improve rumen digestion by changing the rumen fermentation; thus, the energy losses by methane gas production are reduced, and the acetate:propionate ratio is improved (Russell and Strobel, 1989). However, public concern over the routine use of antibiotics in livestock has increased due to the emergence of antibiotic-resistant bacteria that could represent risks to human health (Russell and Houlihan, 2003). Due to the growing tendency of the addition of growth promoters, such as antibiotics, in 2006 the European Union banned the use of those products on the basis of the precautionary principle that the bacteria would evolve resistance and cause problems for human health.

Consequently, considerable efforts have been employed towards the development of alternative products to antibiotics. Plant extracts and essential oils (EOs) offer an opportunity in this regard (Zhang et al., 2010; Jayasena and Jo, 2013; Cruz et al., 2014; Rivaroli et al., 2016) because several plants produce secondary metabolites with antimicrobial properties (Kouazounde et al., 2016).

EOs are considered potential natural substitutes of antibiotics, improving the performance, the feed efficiency and preventing future health damage to consumers, derived from the antibiotics residues. Therefore, they are an alternative for optimizing beef cattle production systems. The use and effects of EOs and their components on ruminal fermentation in vitro have been previously studied by others researchers (Chaves et al., 2008, 2011). However, beef cattle performance in vivo has scarcely been studied in relation to in vitro research.

The EOs (clove and cinnamon) were select according to previous study (Biondo et al., 2017) that demonstrated its higher antioxidant power. In addition, clove and cinnamon EOs had also showed antimicrobial activity, affecting the ruminal microorganisms (Chaves et al., 2008; Patra and Yu, 2012; Patra, 2011).

The main compounds present in clove essential oil (Eugenia caryophyllus) are eugenol, carophylenne and acetate of eugenila, and in cinnamon essential oil (Cinnamon zeylanicum) are cinnamaldehyde, benzaldeide, cinamic alcohol and cumarina (Biondo et al., 2017). Eugenol and cinnamaldehyde have a great ability to modify the microbial fermentation in the rumen and may improve nutrient utilization in ruminants. These properties are similar in both compounds due to the presence of chemical compounds from the same class (Phenylpropanoides) (Benchaar et al., 2008; Hristov et al., 2008; Geraci et al., 2012). These are some of the most important compounds widely used in human medicine with a potent antioxidant, antibacterial and fungicidal power (Hart et al., 2008).

Volatile and odorant compounds from EOs have a potential addition as feed additives in animal nutrition due to palatably properties (Franz et al., 2010), but they also have an activity in the temperament of animals, working in the nostrils by sending signals to the central nervous system and releasing endorphins that affect the feeling of animal welfare (Broughan, 2002). Little research in relation to animal temperament fed with essential oil has been done. Thus, this study was conducted to evaluate the animal performance, temperament, ingestion behaviour and carcass characteristics of young bulls finished in a feedlot fed with highgrain diets and with addition of EOs from clove and cinnamon as an additive.

\section{Materials and methods}

\subsection{Animals, diets, ethic committee and local}

This experiment was approved by the Department of Animal Production and Research Ethic Committee at the State University of Maringá, and it followed the guiding principles of biomedical research with animals $n^{\circ} 081 / 2014$. The study was conducted at the Rosa \& Pedro Sector, State University of Maringá, Experimental Farm Station at Iguatemi city, Paraná, southern Brazil. A total of 40 ( $1 \frac{1}{2}$ Brown Swiss $-1 / 2$ Nellore) young bulls (half-brothers) at10 \pm 2.2 months of age and with a body weight (BW) of $219 \pm 11.7 \mathrm{~kg}$ were used in a completely randomized design. The bulls were weighed at the beginning of the experiment and assigned to $10 \mathrm{~m}^{2}$ individual pens, partially covered and with concrete floors.

The bulls were distributed into five treatments according to initial BW. The adaptation period before starting the experiment lasted two weeks, when the concentrate was supplied gradually. The bulls were weighed every 28 days at the trunk balance (Beckehauser Cia. Paranavaí city, Paraná, south Brazil).

The basal diet comprised $900 \mathrm{~g} / \mathrm{kg}$ concentrate and $100 \mathrm{~g} / \mathrm{kg}$ cane sugar pellets, and it was offered ad libitum for 187 days. The feed intake was recorded daily. The basal diet was the same for all animals, formulated to be isonitrogenous and isoenergetics (Table 1) according to NRC (2000). The five experimental diets were as follows: CON - without essential oil, CLO35-inclusion of 3.5 g of essential oil of clove leaf per animal and day $(370,58$, and $5.69 \mathrm{mg} / \mathrm{kg}$ of dry matter/animal per day of eugenol, carophylenne and eugenyl acetate, respectively), CLO70-inclusion of $7.0 \mathrm{~g}$ of essential oil of clove leaf per animal and day (740, 116, and 11.38 mg/kg of dry matter/animal per day of eugenol, carophylenne and eugenyl acetate, respectively), CIN35-inclusion of $3.5 \mathrm{~g}$ of essential oil of cinnamon leaf per animal and day $(350,21$, and $14.35 \mathrm{mg} / \mathrm{kg}$ of dry matter/animal per day of cinnamaldehyde, carophylenne and $\alpha$ pinene, respectively), and CIN70-inclusion of $7.0 \mathrm{~g}$ of essential oil of cinnamon leaf per animal and day (700, 42, and $28.7 \mathrm{mg} / \mathrm{kg}$ of dry matter/animal per day of cinnamaldehyde, carophylenne and $\alpha$-pinene, respectively), the inclusion of EOs was made every 15 days, adjusting the inclusion according to the intake of dry matter/day per animal, to maintain a constant dosage per animal/day.

The clove essential oil contained $845 \mathrm{~g} / \mathrm{kg}, 133 \mathrm{~g} / \mathrm{kg}$ and $13 \mathrm{~g} / \mathrm{kg}$ of eugenol, carophylenne and eugenyl acetate, respectively, and cinnamon essential oil contained $788 \mathrm{~g} / \mathrm{kg}, 47 \mathrm{~g} / \mathrm{kg}$ and $32 \mathrm{~g} / \mathrm{kg}$ of cynnamaldheyde, carophylenne and $\alpha$-pinene, respectively, was determined by Biondo et al. (2017). The EOs were obtained from FERQUIMA ${ }^{\oplus}$ (Vargem Grande Paulista, São Paulo, Brazil) and stored at $4{ }^{\circ} \mathrm{C}$. They had a liquid texture and were mixed with the concentrate in a commercial mixer every two weeks, when the diets were prepared. Hence, the inclusion of EOs was made every 15 days, adjusting the inclusion according to the intake of dry matter/day per animal, to maintain a constant dosage per animal/day. 
Table 1

Ingredients and chemical composition of basal diet ( $\mathrm{g} / \mathrm{kg}$ DM).

\begin{tabular}{ll}
\hline & Diet \\
\hline Ingredients & \\
Sugar cane pellet & 103.1 \\
Cracked corn & 793.1 \\
Soybean meal & 52.8 \\
Premix & 42.2 \\
Limestone & 4.19 \\
Salt & 2.20 \\
Yeast & 0.40 \\
Dicalcium phosphate & 2.20 \\
Chemical composition & \\
Dry matter & 895 \\
Crude protein & 131 \\
Organic matter & 977 \\
Ash & 22.5 \\
Ether extract & 39.8 \\
Neutral detergent fibre & 233 \\
Acid detergent fibre & 123 \\
Total digestible nutrients & 826 \\
Metabolisable energy (MJ/kg DM) & 12.5 \\
Calcium & 5.80 \\
Phosphorus & 3.44 \\
\hline
\end{tabular}

a Premix: magnesium (57 g/kg), sodium (81 g/kg), sulphur (3.75 g/kg), cobalt $(20 \mathrm{mg} / \mathrm{kg})$, copper $(500 \mathrm{mg} / \mathrm{kg})$, iodine $(25 \mathrm{mg} / \mathrm{kg})$, manganese (1500 mg/kg), selenium (10 mg/kg), zinc $(2000 \mathrm{mg} / \mathrm{kg})$, vitamin A (400 $000 \mathrm{UI} / \mathrm{kg}$ ), vitamin D3 (50 $000 \mathrm{UI} / \mathrm{kg}$ ), vitamin E (750 UI/kg), ether extract $(168 \mathrm{~g} / \mathrm{kg})$ and urea $(200 \mathrm{~g} / \mathrm{kg})$.

\subsection{Chemical analyses}

The dry matter (DM) content of the ingredients was determined by oven-drying at $65^{\circ} \mathrm{C}$ for $24 \mathrm{~h}$ and then drying at $135^{\circ} \mathrm{C}$ for $3 \mathrm{~h}$ (Method 930.15) (AOAC, 2005). The organic matter (OM) content was calculated as the difference between the DM and ash contents, with ash determined by combustion at $550{ }^{\circ} \mathrm{C}$ for $5 \mathrm{~h}$ (AOAC, 2005). The $\mathrm{N}$ content in the samples was determined by the Kjeldahl (Method 976.05) (AOAC, 2005). The neutral detergent fibre (NDF) and acid detergent fibre (ADF) contents were determined using the methods described by Van Soest et al. (1991) with heat stable $\alpha$-amylase and sodium sulphite used in the NDF procedure and expressed inclusive of residual ash. For converting metabolisable energy requirement into digestible energy requirements, the factor of 0.82 was used, and for conversion into total digestible nutrients requirement, the factor 4.1868 MJ was used (NRC, 2000). The antioxidant power of the ration (ORAC method - Oxygen Radical Absorbance Capacity) assay was performed as described by Zulueta et al. (2009).

\subsection{Digestibility trial}

The digestibility of the dry matter (DMD) was obtained using the method described by Tilley and Terry (1963) and modified by Holden (1999) using an artificial rumen developed by ANKOM ${ }^{\circ}$ (Daisy II - Technology Corporation). For the rumen fluid collection two cows weighing approximately $550 \mathrm{~kg}$ fitted with ruminal fistula were used. Collection was performed before feeding a diet of seasonal green forage and supplemented with concentrates consisted of basal diet (without essential oils) (Table 1), in which a 14 day period was used for the adaptation of the animals to the diet. The samples used in the DMD analysis were triturated in a $1.0 \mathrm{~mm}$ sieve and weighed in triplicate, approximately $0.5 \mathrm{~g}$ of MS in nylon filter bags (F57-ANKOM ${ }^{\circ}$ ) with the dimensions of $6.0 \times 6.0 \mathrm{~cm}$ mesh and $30 \mu \mathrm{M}$, sealed and incubated in a jug in a DAISYII machine with 25 bags per vial. The experimental diets were incubated with the buffer solution for $48 \mathrm{~h}$ and then, pepsin and hydrochloric acid were added for 24 additional hours. The in vitro digestibility of DM, crude protein (CP) and NDF were obtained by the following calculations: [(weight of DM incubated - weight of DM residual)/weight of DM incubated], [(weight of CP incubated weight of CP residual)/weight of CP incubated], and [(weight of NDF incubated weight of NDF residual)/weight of NDF incubated], respectively.

\subsection{Animal temperament}

Temperament was evaluated by calculating the chute, exit and temperament scores. The chute score was assessed based on a 5point scale, where 1 = calm with no movement; 2 = restless movements; 3 = frequent movement with vocalization; $4=$ constant movement, vocalization, shaking of the chute; and $5=$ violent and continuous struggling (Arthington et al., 2008). The exit score was assessed by determining the speed of the bulls exiting the squeeze chute by measuring the rate of travel over a $2 \mathrm{~m}$ distance with an infrared sensor (FarmTek Inc., North Wylie, TX). Furthermore, young bulls were divided into quintiles according to their exit 
velocity and assigned a score from 1 to 5 (exit score: 1 = slowest young bulls; 5 = fastest young bulls). Individual temperament scores were calculated by averaging the steer chute score and exit score. These analyses were recorded every 28 days combined with the moment of weighing and divided into six periods.

\subsection{Feeding behaviour activities}

In order to measure the feeding behaviour, the young bulls were subjected to two periods of $24 \mathrm{~h}$ of observation, within five minutes interval, totalling 288 observations for each animal, performed by three evaluators along the feedlot. Animals were adapted for five days prior to the start of evaluations. Water and feed intake, rumination and idle periods were obtained by the sum of 288 observations (minute/day). Observations were performed without interfering the animals routine. The water and feed intake were measured as the time animals spent drinking and eating at the water cooler and at the feeder respectively. Rumination was measured as the time animals presented ruminal bolus and chewing and idle as the time animals spent on idle (Silva et al., 2006).

\subsection{Carcass measurements and meat sampling}

At day 187 in the feedlot, the animals were weighed after $16 \mathrm{~h}$ of fasting $(487 \pm 31.9 \mathrm{~kg})$ and transported to a commercial slaughterhouse (Arapongas city, Paraná, South Brazil). The truck stocking density was $0.8 \pm 0.2 \mathrm{bulls} / \mathrm{m}^{2}$, and the transport distance was less than $60 \mathrm{~km}$. The young bulls were slaughtered following the usual practices of the Brazilian beef industry. The animals were stunned using a captive-bolt pistol. Then, they were bled through exsanguinations by cutting the neck vessels, and the head hide, viscera, tail, legs, diaphragm and excess internal fat were removed. Afterwards, the carcasses were divided medially from the sternum and spine, resulting in two similar halves, which were weighed to calculate the hot carcass weight. Then, the half-carcasses were washed, identified and stored in a chilling chamber at $4{ }^{\circ} \mathrm{C}$, where they remained for a $24 \mathrm{~h}$ period and drip loss measured by the difference between the hot carcass weight and the carcass weight observed $24 \mathrm{~h}$ later after chilling.

The cold carcass dressing (CCD) percentage was defined as the cold carcass weight divided by the final body weight (FBW) $16 \mathrm{~h}$ before slaughter and calculated by applying the following equation: $\mathrm{CCD}=(\mathrm{CCW} / \mathrm{FBW}) \times 100$, where CCW $=$ cold carcass weight.

The fat thickness was measured at $24 \mathrm{~h}$ post mortem on the subcutaneous fat at the level of the 12 th rib after a cross-section in the Longissimus muscle, with a digital calliper model with a reading accuracy of $150 \mathrm{~mm} / 6^{\prime \prime} 0.01 \mathrm{~mm}$ (King tools, São Paulo - Brazil).

The Longissimus muscle area was measured on a transverse cut between the 12th and 13th ribs, with a compensating planimeter. Marbling was measured on the LM from the 12th rib using the Brazilian scoring system (18-16 - abundant, 15-13 - moderate, 12-10 - mean, 9-7 - small, 6-4 - light, and 3-1 - traces). The pH was determined with a pH metre (Hanna instruments model HI99163, Romaria - Brazil); the electrode was calibrated and inserted into the muscle between the 12th and 13th ribs at and $24 \mathrm{~h}$ post slaughtering. The tissue carcass composition was determined by the physical separation of the components (muscle, fat, bone and other tissues) from the 6th rib, and the percentage of each was calculated (Robelin and Geay, 1975).

\subsection{Statistical analyses}

All variables under study were tested for normality and showed a normal distribution. The animal performance, digestibility, temperament, feeding behaviour and carcass characteristics were submitted to an analysis of variance (ANOVA) using the mix model procedure with SAS 9.0 (Institute Inc., Cary, NC) for Windows. Orthogonal contrast was used to assess the effects of the treatment control versus EOs (clove and cinnamon), and linear response $(P \leq 0.05)$. In all statistical analyses, the diet was considered a fixed effect, and the animals were considered a random effect. In addition, for temperament, the period was also considered a fixed effect to calculate the interaction between period and diet and differences between means were evaluated using a Tukey's test $(P \leq 0.05)$. The mean and standard error of the means (SEM) were calculated for each variable.

\section{Results}

\subsection{Animal performance, feed intake and feed efficiency}

The FBW and average daily gain (ADG) were higher $(P<0.01)$ for bulls fed with EOs than for control diet and increased linearly when EOs was added ( $\mathrm{P} \leq 0.05$ ) (Table 2). The dry matter intake (DMI) and other nutrients intake (CP, NDF, ADF and metabolisable energy intake) were increased $(P<0.05)$ in any diet with addition of EOs when compared to control diet. However, feed efficiency was similar $(P=0.23)$ for all the diets (Table 2$)$.

\subsection{In vitro digestibility trial, animal temperament and ingestion behaviour activities}

The addition of EOs to the diet of young bulls had no effect on DMD $(P=0.19)$, CP $(P=0.52)$ and NDF $(P=0.21)$ at in vitro digestibility (Table 3). The exit, chute and temperament scores were not affected by the addition of EOs in the diet (Table 4). The same variables were analysed also for six periods (28 days each). The exit score was similar among the six periods. However, the chute and temperament scores were higher $(P<0.01)$ only in the first period compared with the other periods. There was no interaction between diet and periods in all analyses $(P>0.05)$. The water ingestion, rumination, feeding and idle times were not affected $(P>0.05)$ by the addition of EOs (Table 5$)$. 
Table 2

Animal performance and feed intake of young bulls with essential oils in the diet.

\begin{tabular}{|c|c|c|c|c|c|c|c|c|c|c|c|}
\hline & \multicolumn{5}{|c|}{ Experimental diets } & \multirow[t]{2}{*}{$S E M^{\mathrm{f}}$} & \multicolumn{5}{|c|}{$P$-value } \\
\hline & $\mathrm{CON}^{\mathrm{a}}$ & $\mathrm{CLO}^{\mathrm{b}}{ }^{\mathrm{b}}$ & $\mathrm{CLO}^{\circ}{ }^{\mathrm{c}}$ & $\mathrm{CIN}^{\mathrm{d}}{ }^{\mathrm{d}}$ & $\mathrm{CIN70}^{\mathrm{e}}$ & & Diet effect ${ }^{g}$ & CLO $^{\mathrm{h}}$ vs control & $\mathrm{CIN}^{\mathrm{i}}$ vs control & $\mathrm{CLO}_{\mathrm{L}}^{\mathrm{j}}$ & $\mathrm{CIN}_{\mathrm{L}}{ }^{\mathrm{k}}$ \\
\hline Initial body weight, $\mathrm{kg}$ & 216 & 220 & 219 & 219 & 219 & 2.33 & 0.99 & 0.67 & 0.68 & 0.68 & 0.75 \\
\hline Final body weight, kg & 455 & 501 & 506 & 481 & 488 & 5.79 & 0.01 & 0.01 & 0.03 & 0.01 & 0.05 \\
\hline Average daily gain, $\mathrm{kg} /$ day & 1.28 & 1.50 & 1.53 & 1.40 & 1.44 & 0.03 & 0.01 & 0.01 & 0.04 & 0.01 & 0.11 \\
\hline Dry matter intake, $\mathrm{kg} /$ day & 6.94 & 7.88 & 8.09 & 7.77 & 7.86 & 0.13 & 0.01 & 0.01 & 0.01 & 0.01 & 0.03 \\
\hline Crude protein intake, $\mathrm{kg}$ /day & 0.92 & 1.04 & 1.07 & 1.02 & 1.04 & 0.02 & 0.03 & 0.01 & 0.01 & 0.01 & 0.04 \\
\hline Neutral detergent fiber intake, $\mathrm{kg} /$ day & 2.02 & 2.30 & 2.37 & 2.26 & 2.29 & 0.03 & 0.02 & 0.01 & 0.01 & 0.01 & 0.03 \\
\hline Acid detergent fiber intake, kg/day & 0.86 & 0.98 & 1.01 & 0.97 & 0.98 & 0.02 & 0.02 & 0.01 & 0.01 & 0.01 & 0.03 \\
\hline Metabolisable energy intake, MJ/day & 85.3 & 96.9 & 99.9 & 95.3 & 96.1 & 0.10 & 0.02 & 0.01 & 0.01 & 0.01 & 0.03 \\
\hline Feed efficiency, kg gain/DM intake & 0.18 & 0.19 & 0.19 & 0.18 & 0.18 & 0.01 & 0.23 & 0.18 & 0.65 & 0.22 & 0.53 \\
\hline
\end{tabular}

${ }^{\mathrm{a}} \mathrm{CON}=$ control (no essential oil).

${ }^{\mathrm{b}}$ CLO35 $=3.5 \mathrm{~g} /$ day clove essential oil.

${ }^{\mathrm{c}} \mathrm{CLO70}=7.0 \mathrm{~g} /$ day clove essential oil.

${ }^{\mathrm{d}}$ CIN35 $=3.5 \mathrm{~g} /$ day cinnamon essential oil.

${ }^{\mathrm{e}}$ CIN70 $=7.0 \mathrm{~g} /$ day cinnamon essential oil.

${ }^{\mathrm{f}}$ Standard error of means.

${ }^{g} P$-value ANOVA.

${ }^{\mathrm{h}}$ CLO (3.5 and 7.0 g/day clove essential oil).

${ }^{\mathrm{i}} \mathrm{CIN}=(3.5$ and $7.0 \mathrm{~g} /$ day cinnamon essential oil $)$.

${ }^{\mathrm{j}} \mathrm{CLO}_{\mathrm{L}}=$ linear effect.

${ }^{\mathrm{k}} \mathrm{CIN}_{\mathrm{L}}=$ linear effect

Table 3

In vitro digestibility of young bulls with essential oils in the diet.

\begin{tabular}{|c|c|c|c|c|c|c|c|c|c|c|c|}
\hline \multirow[t]{2}{*}{ Digestibility, g/kg } & \multicolumn{5}{|c|}{ Experimental diets } & \multirow[t]{2}{*}{$S E M^{f}$} & \multicolumn{5}{|c|}{$P$-value } \\
\hline & $\mathrm{CON}^{\mathrm{a}}$ & $\mathrm{CLO}^{2} 5^{\mathrm{b}}$ & $\mathrm{CLO}^{\circ}{ }^{\mathrm{c}}$ & CIN $35^{\mathrm{d}}$ & $\mathrm{CIN70}^{\mathrm{e}}$ & & Diet effect ${ }^{g}$ & $\mathrm{CLO}^{\mathrm{h}}$ vs control & $\mathrm{CIN}^{\mathrm{i}}$ vs control & $\mathrm{CLO}_{\mathrm{L}}{ }^{\mathrm{j}}$ & $\mathrm{CIN}_{\mathrm{L}}{ }^{\mathrm{k}}$ \\
\hline $\mathrm{DM}^{1}$ & 744 & 769 & 753 & 773 & 763 & 0.43 & 0.19 & 0.22 & 0.17 & 0.13 & 0.12 \\
\hline $\mathrm{CP}^{\mathrm{m}}$ & 751 & 720 & 708 & 717 & 694 & 1.75 & 0.52 & 0.38 & 0.11 & 0.76 & 0.26 \\
\hline $\mathrm{NDF}^{\mathrm{n}}$ & 394 & 414 & 356 & 370 & 398 & 0.87 & 0.21 & 0.25 & 0.70 & 0.62 & 0.45 \\
\hline
\end{tabular}

${ }^{\text {a }} \mathrm{CON}=$ control (no essential oil).

${ }^{\text {b }}$ CLO35 $=3.5 \mathrm{~g} /$ day clove essential oil.

${ }^{c} \mathrm{CLO70}=7.0 \mathrm{~g} /$ day clove essential oil.

${ }^{\mathrm{d}} \mathrm{CIN} 35=3.5 \mathrm{~g} /$ day cinnamon essential oil.

e CIN70 $=7.0 \mathrm{~g} /$ day cinnamon essential oil.

f Standard error of means.

${ }^{g} P$-value ANOVA.

${ }^{\mathrm{h}}$ CLO (3.5 and $7.0 \mathrm{~g} /$ day clove essential oil).

${ }^{\mathrm{i}} \mathrm{CIN}=(3.5$ and $7.0 \mathrm{~g} /$ day cinnamon essential oil $)$.

${ }^{j} \mathrm{CLO}_{\mathrm{L}}=$ linear effect.

${ }^{\mathrm{k}} \mathrm{CIN}_{\mathrm{L}}=$ linear effect.

${ }^{1}$ Dry matter.

${ }^{\mathrm{m}}$ Crude protein.

${ }^{\mathrm{n}}$ Neutral detergent fibre.

Table 4

Animal temperament of young bulls with essential oils in the diet.

\begin{tabular}{|c|c|c|c|c|c|c|c|c|c|c|c|c|c|c|c|}
\hline & \multicolumn{6}{|c|}{ Periods $^{1}$} & \multicolumn{5}{|c|}{ Experimental diets } & \multirow[t]{2}{*}{$S E M^{7}$} & \multicolumn{3}{|c|}{$P$-value } \\
\hline & $\mathrm{P} 1$ & P2 & P3 & $\mathrm{P} 4$ & P5 & P6 & $\mathrm{CON}^{2}$ & $\mathrm{CLO}^{3} 5^{3}$ & $\mathrm{CLO}^{4} 0^{4}$ & CIN $35^{5}$ & $\mathrm{CIN}^{6} 0^{6}$ & & $\mathrm{P}^{8}$ & $\mathrm{~T}^{9}$ & $\mathrm{PxT}^{10}$ \\
\hline Chute score & $1.85 \mathrm{a}$ & $1.40 \mathrm{~b}$ & $1.35 b$ & $1.33 \mathrm{~b}$ & $1.20 \mathrm{~b}$ & $1.17 \mathrm{~b}$ & 1.27 & 1.46 & 1.40 & 1.35 & 1.44 & 0.46 & $<0.01$ & 0.71 & 0.92 \\
\hline Velocity Score & 1.57 & 1.80 & 2.98 & 2.02 & 2.73 & 2.66 & 2.49 & 1.86 & 2.03 & 2.15 & 1.93 & 0.19 & 0.21 & 0.06 & 0.91 \\
\hline Temperament Score. & $2.31 \mathrm{a}$ & $1.81 \mathrm{~b}$ & $1.67 \mathrm{~b}$ & $1.69 \mathrm{~b}$ & $1.50 \mathrm{~b}$ & $1.56 \mathrm{~b}$ & 1.77 & 1.67 & 1.72 & 1.71 & 1.92 & 0.05 & $<0.01$ & 0.55 & 0.99 \\
\hline
\end{tabular}

Periods ${ }^{1}$ : Period 1-6.

${ }^{2} \mathrm{CON}=$ control (no essential oil); ${ }^{3} \mathrm{CLO} 35=3.5 \mathrm{~g} /$ day clove essential oil; ${ }^{4} \mathrm{CLO} 70=7.0 \mathrm{~g} /$ day clove essential oil; ${ }^{5} \mathrm{CIN} 35=3.5 \mathrm{~g} / \mathrm{day}$ cinnamon essential oil; ${ }^{6} \mathrm{CIN70}=7.0 \mathrm{~g} /$ day cinnamon essential oil; ${ }^{7}$ Standard error of means; ${ }^{8} \mathrm{P}=$ effect of period; ${ }^{9} \mathrm{~T}=$ effect of treatments; ${ }^{10} \mathrm{PxT}=$ interaction between period and treatments. $\mathrm{a}-\mathrm{b}=$ Means followed by different letters in the same row are different $(P<0.05)$. 
Table 5

Feeding behaviour activities of young bulls with essential oils in the diet.

\begin{tabular}{|c|c|c|c|c|c|c|c|c|c|c|c|}
\hline \multirow[t]{2}{*}{ Activities, min/day } & \multicolumn{5}{|c|}{ Experimental diets } & \multirow[t]{2}{*}{$S E M^{\mathrm{f}}$} & \multicolumn{5}{|c|}{$P$-value } \\
\hline & $\mathrm{CON}^{\mathrm{a}}$ & $\mathrm{CLO}^{\mathrm{b}}{ }^{\mathrm{b}}$ & $\mathrm{CLO}^{\circ}{ }^{\mathrm{C}}$ & $\mathrm{CIN}^{\mathrm{d}}{ }^{\mathrm{d}}$ & CIN70 $^{\mathrm{e}}$ & & Diet effect ${ }^{g}$ & $\mathrm{CLO}^{\mathrm{h}}$ vs control & $\mathrm{CIN}^{\mathrm{i}}$ vs control & $\mathrm{CLO}_{\mathrm{L}}^{\mathrm{j}}$ & $\mathrm{CIN}_{\mathrm{L}}{ }^{\mathrm{k}}$ \\
\hline Water ingestion & 42.5 & 42.5 & 39.4 & 38.8 & 46.2 & 2.91 & 0.94 & 0.86 & 1.00 & 1.00 & 0.69 \\
\hline Feed intake & 389 & 333 & 389 & 378 & 359 & 10.7 & 0.42 & 0.32 & 0.52 & 0.10 & 0.76 \\
\hline Rumination & 63.7 & 78.8 & 83.8 & 67.5 & 88.7 & 6.22 & 0.70 & 0.34 & 0.38 & 0.48 & 0.84 \\
\hline Idle & 954 & 995 & 937 & 965 & 955 & 11.4 & 0.60 & 0.70 & 0.86 & 0.27 & 0.77 \\
\hline
\end{tabular}

${ }^{\mathrm{a}} \mathrm{CON}=$ control (without essential oil).

${ }^{\mathrm{b}}$ CLO35 $=3.5 \mathrm{~g} /$ day clove essential oil.

${ }^{\mathrm{c}} \mathrm{CLO} 70=7.0 \mathrm{~g} /$ day clove essential oil.

${ }^{\mathrm{d}}$ CIN35 $=3.5 \mathrm{~g} /$ day cinnamon essential oil.

${ }^{\mathrm{e}}$ CIN70 $=7.0 \mathrm{~g} /$ day cinnamon essential oil.

${ }^{f}$ Standard error of means.

${ }^{g} P$-value ANOVA.

${ }^{\text {h }}$ CLO (3.5 and $7.0 \mathrm{~g} /$ day clove essential oil).

${ }^{\mathrm{i}} \mathrm{CIN}=(3.5$ and $7.0 \mathrm{~g} /$ day cinnamon essential oil $)$.

${ }^{\mathrm{j}} \mathrm{CLO}_{\mathrm{L}}=$ linear effect.

${ }^{\mathrm{k}} \mathrm{CIN}_{\mathrm{L}}=$ linear effect.

\subsection{Carcass characteristics}

The CCW (Table 6) was higher $(P=0.03$ ) for cattle fed with clove and cinnamon oils than for cattle fed without EOs following the same pattern as animal performance results. Clove essential oil increased linearly CCW $(P=0.01)$ while cinnamon essential oil tended to increase CCW linearly $(P=0.09)$. Significant differences in cold dressing carcass $(P=0.18)$ or dripping losses were not observed $(P=0.69)$. The carcass composition from the 6 th rib did not differ $(P>0.05)$ between diets. All diets presented a similar percentage of muscle, fat, bone and other tissues. The fat thickness, marbling, area of the Longissimus muscle or $24 \mathrm{~h}$ pH did not differ among diets.

Table 6

Carcass characteristics of young bulls with essential oils in the diet.

\begin{tabular}{|c|c|c|c|c|c|c|c|c|c|c|c|}
\hline \multirow[t]{2}{*}{ Parameters } & \multicolumn{5}{|c|}{ Experimental diets } & \multirow[t]{2}{*}{$S E M^{\mathrm{f}}$} & \multicolumn{5}{|l|}{$P$-value } \\
\hline & $\mathrm{CON}^{\mathrm{a}}$ & $\mathrm{CLO}^{\mathrm{b}}{ }^{\mathrm{b}}$ & $\mathrm{CLO}^{\circ}{ }^{\mathrm{c}}$ & $\mathrm{CIN}^{\mathrm{d}}{ }^{\mathrm{d}}$ & $\mathrm{CIN70}^{\mathrm{e}}$ & & Diets effect ${ }^{g}$ & $\mathrm{CLO}^{\mathrm{h}}$ vs control & $\mathrm{CIN}^{\mathrm{i}}$ vs control & $\mathrm{CLO}_{\mathrm{L}}^{\mathrm{j}}$ & $\mathrm{CIN}_{\mathrm{L}}{ }^{\mathrm{k}}$ \\
\hline Cold carcass weight, kg & 246 & 273 & 282 & 263 & 266 & 3.72 & 0.03 & 0.01 & 0.04 & 0.01 & 0.09 \\
\hline Cold dressing carcass, $\%$ & 54.0 & 54.5 & 55.6 & 54.7 & 54.6 & 0.21 & 0.18 & 0.10 & 0.25 & 0.46 & 0.24 \\
\hline Dripping losses, \% & 1.20 & 1.24 & 1.25 & 1.50 & 1.39 & 0.07 & 0.69 & 0.84 & 0.23 & 0.88 & 0.20 \\
\hline Fat thickness, mm & 3.66 & 3.77 & 4.01 & 4.21 & 3.90 & 0.95 & 0.40 & 0.38 & 0.14 & 0.70 & 0.81 \\
\hline Longissimus muscle area $\mathrm{cm}^{2}$ & 74.2 & 85.5 & 86.7 & 84.6 & 76.5 & 1.75 & 0.06 & 0.11 & 0.17 & 0.23 & 0.36 \\
\hline Marbling, points & 4.12 & 4.75 & 4.12 & 4.37 & 4.12 & 0.14 & 0.70 & 0.46 & 0.77 & 0.21 & 0.61 \\
\hline \multicolumn{12}{|l|}{ Tissue composition ( $6^{\text {th }}$ rib) } \\
\hline Muscle, $\%$ & 61.5 & 60.7 & 61.7 & 60.2 & 62.5 & 0.65 & 0.83 & 0.87 & 0.93 & 0.73 & 0.50 \\
\hline Fat, \% & 16.4 & 17.3 & 16.0 & 15.9 & 13.8 & 0.55 & 0.38 & 0.87 & 0.24 & 0.66 & 0.75 \\
\hline Bone, \% & 16.3 & 16.5 & 16.8 & 17.6 & 18.1 & 0.48 & 0.74 & 0.79 & 0.29 & 0.91 & 0.43 \\
\hline Others, \% & 5.75 & 5.45 & 5.41 & 6.22 & 5.48 & 0.28 & 0.89 & 0.67 & 0.93 & 0.73 & 0.68 \\
\hline $\mathrm{pH} 24 \mathrm{~h}$ & 5.60 & 5.60 & 5.60 & 5.60 & 5.60 & 0.02 & 0.76 & 0.85 & 0.78 & 0.92 & 0.82 \\
\hline
\end{tabular}

${ }^{\text {a }} \mathrm{CON}=$ control (without essential oil).

${ }^{\mathrm{b}} \mathrm{CLO} 35=3.5 \mathrm{~g} /$ day clove essential oil.

${ }^{\text {c }}$ CLO70 $=7.0 \mathrm{~g} /$ day clove essential oil.

${ }^{\mathrm{d}}$ CIN35 $=3.5 \mathrm{~g} /$ day cinnamon essential oil.

${ }^{\mathrm{e}}$ CIN70 $=7.0 \mathrm{~g} /$ day cinnamon essential oil.

${ }^{\mathrm{f}}$ Standard error of means.

${ }^{g} P$-value ANOVA.

${ }^{\mathrm{h}}$ CLO (3.5 and $7.0 \mathrm{~g} /$ day clove essential oil).

${ }^{\mathrm{i}} \mathrm{CIN}=(3.5$ and $7.0 \mathrm{~g} /$ day cinnamon essential oil $)$.

${ }^{\mathrm{j}} \mathrm{CLO}_{\mathrm{L}}=$ linear effect.

${ }^{\mathrm{k}} \mathrm{CIN}_{\mathrm{L}}=$ linear effect. 


\section{Discussion}

\subsection{Animal performance, feed intake and feed efficiency}

Natural additives have the potential to modulate rumen fermentation and improve animal performance (Fandiño et al., 2008; Geraci et al., 2012; Valero et al., 2014a). Additionally, EOs can be used as natural products without the problems faced by ionophores and growth promoters in beef production. These problems are related to residues in the final products, which might be harmful to human health (Russell and Houlihan, 2003). In the present study, animal performance was improved by the addition of cinnamon and clove essential oils (Table 2). This improvement might be associated with the volatile and odorant compounds of the EOs since the ingestion of DM was higher for the animals fed with EOs, demonstrating the palatability of these oils.

In the current study, DMI increased when clove or cinnamon oils were included in the diets improving the growth performance. Previous study had already shown the palatability effect of the EOs (Franz et al., 2010). Corroborating with our study, Yang et al. (2014) found significant difference in DMI the addition of levels of cinnamaldehyde (400, 800, $1600 \mathrm{mg} /$ day per animal) on the first 28 days when compared with the control diet in feedlot cattle. Fandiño et al. (2008) observed increases in DMI when EOs (anise) were added ( $500 \mathrm{mg} /$ day) as an alternative to monensin in beef heifers fed a high-concentrate diet but not in feed efficiency, similar to the present study. On the other hand, Khorrami et al. (2015) used $500 \mathrm{mg} / \mathrm{kg}$ of thyme and cinnamon EOs in the Holstein steers diet and found significant differences in DMI. Chaves et al. (2008, 2011) reported no changes in DMI in lambs supplemented with carvacrol, cinnamaldehyde and juniper berry at different concentrations (from 100 to $400 \mathrm{mg} / \mathrm{DM}$ per $\mathrm{kg}$ ), probably associated to the lower concentration used. These differences can be related to the compounds used and differences between the species. Moreover, these results might be related to the antimicrobial activity of the EOs used.

According to Calsamiglia et al. (2007), the inclusion of a mix of several EOs in ruminant diets may improve animal performance due to the antimicrobial activity of essential oil compounds. Other authors (Benchaar et al., 2008; Hart et al., 2008) have shown that plant extracts may be useful alternatives to antibiotics because many plants produce secondary metabolites which have antimicrobial properties. Similarly, the well-documented antimicrobial activity of the active components of EOs has prompted a number of researchers to examine the ability of these secondary metabolites to manipulate rumen fermentation (Calsamiglia et al., 2007; Hart et al., 2008; Hristov et al., 2008; Jayasena and Jo, 2013; Cruz et al., 2014). All of these results could explain our findings.

Furthermore, high-grain diets end to present lower ruminal $\mathrm{pH}$, making it more moderately acidic, which enhances the action of EOs (Calsamiglia et al., 2007). Thus, the eugenol present in clove essential oil, may act in rumen defaunation (protozoa) and consequently of Archeas (methanogenic), which live adhered with these microorganisms (McIntosh et al., 2003; Newbold et al., 2004), reducing the ratio of acetate:propionate and decreasing the production of methane, reducing energy expenditure, leading a better animal performance. In a study performed by Yang et al. (2010) providing eugenol doses (0, 400, 800, 1600 mg/day per animal) in the diet of growing beef, an increase in propionate and a linear decrease of the acetate:propionate ratio were reported.

Although, the feed efficiency was similar with or without the essential oil addition in the diet, animals that received clove essential oil might be finished in feedlot in a short time due to the highest average daily gain.

\subsection{In vitro digestibility trial}

Available information about the effect of the addition of EOs on ruminant digestion is limited. The DMD averaged $760 \mathrm{~g} / \mathrm{kg}$ in the five treatments, $718 \mathrm{~g} / \mathrm{kg} \mathrm{CP}$ and $386 \mathrm{~g} / \mathrm{kg}$ NDF. Thus, the addition of essential oil in the diet of ruminants did not change the DMD among the diets (Table 5). Our results are in agreement with those from Khorrami et al. (2015) that showed that the addition of thyme and cinnamon EOs (500 mg/kg DM) had no effect on apparent digestibility of nutrients in Holstein steers. Valero et al. (2014a, 2016) observed an apparent digestibility close to the values observed in this study in bulls finished in a feedlot and supplemented with $3 \mathrm{~g}$ /animal per day of EOs (ricinoleic acid extracted from castor oil seed and anacardic acid, cardanol and cardol extracted from cashew nutshell liquid). Benchaar et al. (2006a) indicated that in beef cattle the dry matter digestibility and nitrogen digestibility are not changed by the addition of EOs in the diet. In dairy cows Benchaar et al. (2006b) observed that the apparent digestibility of DM, OM, NDF and starch were similar among animals fed the control diet and those supplemented with EOs or sodium monensin. Likewise, Ando et al. (2003) observed no changes in total tract digestibility of dry matter and crude protein when steers were fed peppermint ( $200 \mathrm{~g} / \mathrm{steer}$ per day) in which menthol is the main functional oil. Castillejos et al. (2005) observed no effect on nitrogen degradation when a mixture of EOs (Crina Ruminants ${ }^{\circledR}$ ) was added to continuous culture fermenters.

\subsection{Animal temperament}

To the best of our knowledge there is no information yet referring to temperament using EOs in the current literature. The central nervous system (CNS) is responsible for the progress of the whole body, and there are many barriers, particularly the hematoencephalic barrier that protect it from chemical substances; however, some mode chemicals, such as EOs, can pass through these obstacles. Their action is not guaranteed because these substances can still be metabolized in the CNS (Banks et al., 2008). In all treatments the proper temperament of animals was observed as a score $\leq 3$ as recommended by Cooke et al. (2009).

The analysis of temperament available by chute, exit and temperament scores did not show a significant difference among the diets in any of the 6 periods analysed. The effect of the period on chute score and temperament score was affected only by the periods; the effect of the first period was significantly higher than that of the other periods of the experiment. The observed temperament may be a consequence of the rational management used on the property. According to Cooke et al. (2009), temperament is a learned 
behaviour, and animals can adapt to human management even if they are handled before weaning as was done on the farm of origin. This lack of difference may be associated with the state of the animals (not stressed), as observed in the first evaluation period with a score that indicated a docile animal.

\subsection{Ingestion behaviour activities}

The addition of EOs in the diet did not produce a significant variation in ingestion behaviour. Water ingestion can be affected by dry matter, the ingredients of diets, temperature and the physiological state (NRC, 2000). The rumination time can be particularly affected by the amount, physical form and content of fibre (Van Soest, 1994). However, the rumination time was very low (77 min/ 1440 min of observation time) because the diet presents a ratio of 90:10 concentrate and forage. This high-grain ratio affects the production of saliva and consequently influences rumination.

The idle time can positively affect animal performance. The time used in other activities (walking, for example) leads to energy expenditure. Thus, animal in the idle process reduce the energy expenditure; grounded in this fact, in this work the idle time observed was high, 962 min over 1440 min of observation. Segabinazzi et al. (2011) fed cull cows with plant extracts (5 g/animal per day) of a natural additive comprising $750 \mathrm{mg}$ of thyme (Thymus vulgaris) essential oil, $150 \mathrm{mg}$ of garlic (Allium sativum), $250 \mathrm{mg}$ of rosemary extract (Rosmarinus officinalis), $250 \mathrm{mg}$ of canola oil (Brassica napus) and $250 \mathrm{mg}$ extract of quillaja (Quillaja saponaria) with sodium monensin, and they did not obtain significant differences when observed the idle time in comparison with a control diet.

\subsection{Carcass characteristics}

Usually, young (up to 24-month-old) and crossbred (Bos taurus $x$ Bos indicus) bulls that are finished in a feedlot have a dressing percentage from 52 to 56\% (Prado et al., 2008; Rotta et al., 2009; Dian et al., 2010; Maggioni et al., 2010). Corroborating our data, Yang et al. (2010), using cinnamaldehyde levels (0, 400, 800 and $1600 \mathrm{mg} /$ day per animal) in the diet of beef finished in a feedlot, did not obtain differences in carcass dressing among groups. Likewise, Valero et al. (2014b) did not find differences in carcass dressing from bulls fed ricinoleic acid and anacardic, cardanol and cardol for animals finished in a feedlot.

The values obtained in drip losses (1.3\%) can be considered normal for bull carcasses. The observed fat thickness (around 4 mm) can be considered low. The fat thickness must be between 3 and $6 \mathrm{~mm}$ (Rotta et al., 2009) to protect the carcass during chilling, but carcasses with values greater than $6 \mathrm{~mm}$ can result in economic losses because of the high energetic value of fat deposition (furthermore, fat can be removed during the slaughter process). However, some countries demand carcasses with greater fat thickness.

The muscle, fat and bone percentages after carcass dissection were similar among the five diets and featured average values of $61.3 \%, 15.88 \%$ and $17.06 \%$, respectively. Thus, the inclusion of EOs in the diet had no effect on the tissue percentages in the carcasses of young bulls finished in a feedlot, as was also observed by Valero et al. (2014a) with the addition of castor and cashew nut oils.

The average Longissimus muscle area of the bulls was $82 \mathrm{~cm}^{2}$, which is similar to what Maggioni et al. (2009) found in crossbred beef cattle (Bos taurus $x$ Bos indicus) finished in feedlot with two sources of roughage and the yeast addition. Meat marbling was 4.3 points on average, which is considered a 'light' marbling. The low marbling observed in the current experiment can be explained by the presence of Nellore genes. Beef from the Bos indicus sub-species generally have lower marbling scores than Bos taurus (Rotta et al., 2009).

The $\mathrm{pH}$ is considered adequate when approximately 5.5-5.8, and it is influenced by housing chilling and the stress that the animal suffers ante mortem. The $\mathrm{pH}$ obtained in this experiment (5.6) indicates that the animals were calm and that proper cooling of the carcasses occurred. Recently, Yang et al. (2010) evaluated the cinnamaldehyde levels (400, 800, $1600 \mathrm{mg} / \mathrm{steer}$ per day) in the diet of steers raised in a feedlot, and they did not observe significant differences in carcass characteristics, comparing essential oil treatments with a control or with monensin in the diet, corroborating the data of this study. Chaves et al. (2011) provided cinnamaldehyde doses $(100,200,300,400 \mathrm{mg} / \mathrm{kg}$ of DM) for growing lambs and reported no differences in carcass characteristics.

\section{Conclusions}

The results of this study suggest that clove and cinnamon EOs can be added at levels from 3.5 to $7.0 \mathrm{~g}$ per animal/day in highgrain finished diets as an additive because they improve animal growth performance up to $11 \%$ compared with a control diet without changing feed efficiency, digestibility of nutrients, temperament, animal feeding behaviour or carcass characteristics. Even at lower doses (3.5 g per animal/day) the results showed an improvement in animal performance when the essential oils were used in diet of bulls finished in feedlot, especially for clove essential oil. However, the recommendation for the inclusion of EOs in the diets of cattle finished in a feedlot and fed a high-grain diet depends on the cost of these products on the market and the cost-benefit ratio. Moreover, the effect of the addition of these EOs to high-grain diets on the meat quality and lipid oxidation could be evaluated.

\section{Conflict of interests}

The authors declare no conflict of interests. 


\section{Acknowledgements}

The current project was funded by the Araucaria Foundation, a fund of the state of Paraná and the Brazilian Council for Research and Technological Development (CNPq). The authors thank Ricardo Antonioli Grassano (Arapongas city, Paraná State, Brazil South) for providing the animals used in the research. The trade names or commercial products in this publication are mentioned solely for the purpose of providing specific information and do not imply recommendations or endorsement by the Department of Animal Science, Universidade Estadual de Maringá, Maringá, Paraná, Brazil.

\section{References}

Ando, S., Nishida, T., Ishida, M., Hosoda, K., Bayaru, E., 2003. Effect of peppermint feeding on the digestibility, ruminal fermentation and protozoa. Livest. Prod. Sci. $82,245-248$.

AOAC, 2005. Association Official Analytical Chemist (2005). AOAC, Gaitherburg, Maryland, USA.

Arthington, J.D., Qiu, X., Cooke, R.F., Vendramini, J.M.B., Araujo, D.B., Chase, C.C., Coleman, S.W., 2008. Effects of preshipping management on measures of stress and performance of beef steers during feedlot receiving. J. Anim. Sci. 86, 2016-2023.

Banks, W.A., Burney, B.O., Robinson, S.M., 2008. Effects of triglycerides, obesity, and starvation on ghrelin transport across the blood-brain barrier. Peptides 29, 2061-2065.

Benchaar, C., Duynisveld, J.L., Charmley, E., 2006a. Effects of monensin and increasing dose levels of a mixture of essential oil compounds on intake: digestion and growth performance of beef cattle. Can. J. Anim. Sci. 86, 91-96.

Benchaar, C., Petit, H.V., Berthiaume, R., Whyte, T.D., Chouinard, P.Y., 2006b. Effects of addition of essential oils and monensin premix on digestion, ruminal fermentation, milk production, and milk composition in dairy cows. J. Dairy Sci. 89, 4352-4364.

Benchaar, C., Calsamiglia, S., Chaves, A.V., Fraser, G.R., Colombatto, D., McAllister, T.A., Beauchemin, K.A., 2008. A review of plant-derived essential oils in ruminant nutrition and production. Anim. Feed Sci. Technol. 145, 209-228.

Biondo, P.B.F., Carbonera, F., Zawadzki, F., Chiavellia, L.U.R., Pilau, E.J.P., Prado, I.N., Visentainer, J.V., 2017. Antioxidant capacity and identification of bioactive compounds by GC-MS of essential oils commercialized in Brazil. Curr. Bioact. Compd. 13, 137-143.

Broughan, C., 2002. Odours, emotions, and cognition-how odours may affect cognitive performance. Int. J. Aromather. 12, 92-98.

Calsamiglia, S., Busquet, M., Cardozo, P.W., Castillejos, L., Ferret, A., 2007. Invited review: essential oils as modifiers of rumen microbial fermentation. J. Dairy Sci. 90 , $2580-2595$.

Castillejos, L., Calsamiglia, S., Ferret, A., Losa, R., 2005. Effects of a specific blend of essential oil compounds and the type of diet on rumen microbial fermentation and nutrient flow from a continuous culture system. Anim. Feed Sci. Technol. 119, 29-41.

Chaves, A.V., Stanford, K., Dugan, M.E.R., Gibson, L.L., McAllister, T.A., Van Herk, F., Benchaar, C., 2008. Effects of cinnamaldehyde, garlic and juniper berry essential oils on rumen fermentation blood metabolites, growth performance, and carcass characteristics of growing lambs. Livest. Sci. 117, $215-224$.

Chaves, A.V., Dugan, M.E.R., Stanford, K., Gibson, L.L., Bystrom, J.M., McAllister, T.A., Van Herk, F., Benchaar, C., 2011. A dose-response of cinnamaldehyde supplementation on intake, ruminal fermentation, blood metabolites, growth performance, and carcass characteristics of growing lambs. Livest. Sci. 141, 213-220.

Cooke, R.F., Arthington, J.D., Araujo, D.B., Lamb, G.C., 2009. Effects of acclimation to human interaction on performance, temperament, physiological responses, and pregnancy rates of Brahman-crossbred cows. J. Anim. Sci. 87, 4125-4132.

Cruz, O.T.B., Valero, M.V., Zawadzki, F., Rivaroli, D.C., Prado, R.M., Lima, B.S., Prado, I.N., 2014. Effect of glycerine and essential oils (Anacardium occidentale and Ricinus communis) on animal performance, feed efficiency and carcass characteristics of crossbred bulls finished in a feedlot system. Ital. J. Anim. Sci. 13, 3492.

Dian, P.H.M., Prado, I.N., Valero, M.V., Rotta, P.P., Prado, R.M., Silva, R.R., Bertipaglia, L.M.A., 2010. Levels of replacing corn by cassava starch on performance and carcass characteristics of bulls finished in feedlot. Semina: Cienc. Agrar. 31, 497-506.

Fandiño, I., Calsamiglia, S., Ferret, A., Blanch, M., 2008. Anise and capsicum as alternatives to monensin to modify rumen fermentation in beef heifers fed a high concentrate diet. Anim. Feed Sci. Technol. 145, 409-417.

Franz, C., Baser, K.H.C., Windisch, W., 2010. Essential oils and aromatic plants in animal feeding-a European perspective. A review. Flavour Frag. J. 25, 327-340.

Geraci, J.I., Garciarena, A.D., Gagliostro, G.A., Beauchemin, K.A., Colombatto, D., 2012. Plant extracts containing cinnamaldehyde, eugenol and capsicum oleoresin added to feedlot cattle diets Ruminal environment, short term intake pattern and animal performance. Anim. Feed Sci. Technol. 176, 123-130.

Hart, K.J., Yáñez-Ruiz, D.R., Duval, S.M., McEwan, N.R., Newbold, C.J., 2008. Plant extracts to manipulate rumen fermentation. Anim. Feed Sci. Technol. 147, 8-35.

Holden, L.A., 1999. Comparison of methods of in vitro dry matter digestibility for ten feeds. J. Dairy Sci. 82, 1791-1794.

Hristov, A.N., Ropp, J.K., Zaman, S., Melgar, A., 2008. Effects of essential oils on in vitro ruminal fermentation and ammonia release. Anim. Feed Sci. Technol. 144, 55-64.

Jayasena, D.D., Jo, C., 2013. Essential oils as potential antimicrobial agents in meat and meat products: a review. Trends Food Sci. Technol. 34, 96-108.

Khorrami, B., Vakili, A.R., Mesgaran, M.D., Klevenhusen, F., 2015. Thyme and cinnamon essential oils: potential alternatives for monensin as a rumen modifier in beef production systems. Anim. Feed Sci. Technol. 200, 8-16.

Koulazounde, J.B., Jin, L., McAllister, T.A., Gbenou, J.D., 2016. In vitro screening of selected essential oils from medicinal plants acclimated to Benin for their effects on methane production from rumen microbial fermentation. Afr. J. Biotechnol. 15, 442-450.

Maggioni, D., Marques, J.A., Perotto, D., Rotta, P.P., Ducatti, T., Matsushita, M., Silva, R.R., Prado, I.N., 2009. Bermuda grass hay or sorghum silage with or without yeast addition on performance and carcass characteristics of crossbred young bulls finished in feedlot. Asian-Australas. J. Anim. Sci. 22 , 206-215.

Maggioni, D., Marques, J.A., Rotta, P.P., Perotto, D., Ducatti, T., Visentainer, J.V., Prado, I.N., 2010. Animal performance and meat quality of crossbred young bulls. Livest. Sci. 127, 176-182.

McIntosh, F.M., Williams, P., Losa, R., Wallace, R.J., Beever, D.A., Newbold, C.J., 2003. Effects of essential oils on ruminal microorganisms and their protein metabolism. Appl. Environ. Microbiol. 69, 5011-5014.

NRC, 2000. Nutrient Requirements of Beef Cattle. Natl. Acad. Press, Washington, DC, USA.

Newbold, C.J., McIntosh, F.M., Williams, P., Losa, R., Wallace, R.J., 2004. Effects of a specific blend of essential oil compounds on rumen fermentation. Anim. Feed Sci. Technol. 114, 105-112.

Patra, A.K., Yu, Z., 2012. Effects of essential oils on methane production and fermentation by and abundance and diversity of, rumen microbial populations. Appl. Environ. Microbiol. 78, 4271-4280.

Patra, A.K., 2011. Effects of essential oils on rumen fermentation, microbial ecology and ruminant production. Asian J. Anim. Vet. Adv. 6, 416-428.

Prado, I.N., Rotta, P.P., Prado, R.M., Visantainer, J.V., Moletta, J.L., Perotto, D., 2008. Carcass characteristics and chemical composition of the Longissimus muscle of Purunã and 1/2 Purunã vs. 1/2 Canchin bulls. Asian-Australas. J. Anim. Sci. 21, 1296-1302.

Rivaroli, D.C., Guerrero, A., Valero, M.M., Zawadzki, F., Eiras, C.E., Campo, M.M., Sañudo, C., Jorge, A.M., Prado, I.N., 2016. Effect of essential oils on meat and fat qualities of crossbred young bulls finished in feedlots. Meat Sci. 121, 278-284.

Robelin, J., Geay, Y., 1975. Estimation de la composition des carcasses de jeunes bovins à partir de la composition d'un morceau monocostal prélevé au niveau de la I léme côte. I. Composition anatomique de la carcasse. Ann. Zootech. 24, 391-402.

Rotta, P.P., Prado, R.M., Prado, I.N., Valero, M.V., Visentainer, J.V., Silva, R.R., 2009. The effects of genetic groups, nutrition, finishing systems and gender of Brazilian cattle on carcass characteristics and beef composition and appearance: a review. Asian-Australas. J. Anim. Sci. 22, $1718-1734$.

Russell, J.B., Houlihan, A.J., 2003. Ionophore resistance of ruminal bacteria and its potential impact on human health. FEMS Microbiol. Rev. 27 , 65-74.

Russell, J.B., Strobel, H.J., 1989. Effect of ionophores on ruminal fermentation. Appl. Environ. Microbiol. 55, 1-6. 
Segabinazzi, L.R., Viégas, J., Freitas, L.S., Brondani, I.L., Argenta, F.M., Binotto, J., 2011. Behavior patterns of cows with Charolais or Nellore breed predominance fed diets with plant extract or monensin sodium. Rev. Bras. Zootec. 40, 2954-2962.

Silva, R.R., Silva, F.F., Prado, I.N., Carvalho, G.G.P., Franco, I.L., Almeida, I.C.C., Cardoso, C.P., Ribeiro, M.H.S., 2006. Comportamento ingestivo de bovinos. Aspectos metodológicos. Arch. Zootec. 55, 293-296.

Tilley, J.M.A., Terry, R.A., 1963. A two-stage technique for the in vitro digestion of forage crops. Grass Forage Sci. 18, 104-111.

Valero, M.V., Prado, R.M., Zawadzki, F., Eiras, C.E., Madrona, G.S., Prado, I.N., 2014a. Propolis and essential oils additives in the diets improved animal performance and feed efficiency of bulls finished in feedlot. Acta Scient. Anim. Sci. 36, 419-426.

Valero, M.V., Torrecilhas, J.A., Zawadzki, F., Bonafé, E.G., Madrona, G.S., Prado, R.M., Passetti, R.A.C., Rivaroli, D.C., Veisentainer, J.V., Prado, I.N., 2014b. Propolis or cashew and castor oils effects on composition of Longissimus muscle of crossbred bulls finished in feedlot. Chil. J. Agric. Res. 74, 445-451.

Valero, M.V., Farias, M.S., Zawadzki, F., Prado, R.M., Fugita, C.A., Rivaroli, D.C., Ornaghi, M., Prado, I.N., 2016. Feeding propolis or functional oils (cashew and castor oils) to bulls: performance, digestibility and blood cells counts. Rev. Colomb. Cienc. Pec. 29, 33-42.

Van Soest, P.J., Robertson, J.B., Lewis, B.A., 1991. Methods for dietary fiber, neutral detergent fiber, and nonstarch polysaccharides in relation to animal nutrition. J. Dairy Sci. 74, 3583-3597.

Van Soest, P.J., 1994. Nutritional Ecology of the Ruminant. Cornell University Press, Ithaca, NY, USA.

Yang, W.Z., Benchaar, C., Ametaj, B.N., Beauchemin, K.A., 2010. Dose response to eugenol supplementation in growing beef cattle: ruminal fermentation and intestinal digestion. Anim. Feed Sci. Technol. 158, 57-64.

Yang, W.Z., Ametaj, B.N., Benchaar, C., He, M.L., Beauchemin, K.A., 2014. Cinnamaldehyde in feedlot cattle diets: intake, growth performance, carcass characteristics, and blood metabolites. J. Anim. Sci. 88, 1082-1092.

Zhang, W., Xiao, S., Samaraweera, H., Lee, E.J., Ahn, D.U., 2010. Improving functional value of meat products. Meat Sci. 86, 15-31.

Zulueta, A., Esteve, M.J., Frígola, A., 2009. ORAC and TEAC assays comparison to measure the antioxidant capacity of food products. Food Chem. 114, 310-316. 